https://helda.helsinki.fi

\title{
The ironic effect of national identification on support for collective action
}

\section{Mähönen, Tuuli Anna}

2015

Mähönen , T A \& Jasinskaja-Lahti , I 2015 , ' The ironic effect of national identification on support for collective action ' , European Journal of Social Psychology, vol. 45 , no. 5 , pp. pÿ567 574 . https://doi.org/10.1002/ejsp.2118

http://hdl.handle.net/10138/234352

https://doi.org/10.1002/ejsp.2118

acceptedVersion

Downloaded from Helda, University of Helsinki institutional repository.

This is an electronic reprint of the original article.

This reprint may differ from the original in pagination and typographic detail.

Please cite the original version. 
RUNNING HEAD: NATIONAL IDENTIFICATION, PERCEIVED PERMEABILITY AND

COLLECTIVE ACTION

Accepted author manuscript.

Mähönen, T. A., \& Jasinskaja-Lahti, I. (2015). The ironic effect of national identification on support for collective action. European Journal of Social Psychology, 45(5), 567-574.

The ironic effect of national identification on support for collective action

Tuuli Anna Mähönen* \& Inga Jasinskaja-Lahti**

University of Helsinki, Finland

*Corresponding author: Open University, University of Helsinki, P.O. Box 53, FIN-00014

University of Helsinki, e-mail: tuuli-anna.mahonen@helsinki.fi; tel. +358 504484259

**Department of Social Research (Social Psychology), University of Helsinki

\section{Acknowledgements}

This research was supported by the Academy of Finland research grants No 123297 and No 257079. We thank Tamara Kinunen, Michail Vinokurov, Anu Yijälä, Elina Leinonen, Jesse Haapoja and Elena Waschinski for practical assistance and help with data collection. We also thank Katrina Jurva for language revision. Finally, we wish to thank Dr. Vivian Vignoles for all the constructive comments and diligent work during the review process. 


\begin{abstract}
Previous research has suggested that dual and superordinate identities are prerequisites of collective action among minority group members, but they can also be associated with greater acceptance of the ingroup's disadvantaged position. In this three-wave study among Ingrian Finnish migrants from Russia to Finland $\left(N=153_{\mathrm{T} 1}-85_{\mathrm{T} 3}\right)$, we tested the indirect association between superordinate national identification (T1) and support for collective action (T3), via perceived permeability of group boundaries (T2). Support for collective action was operationalized as one's personal willingness, and the perceived need of the Russian-speaking community, to engage in it. When controlling for the direct association between Russian minority identification and support for collective action, perceived permeability was shown to mediate the negative association between Finnish national identification and support for community's collective action. Thus, being close to the majority may make immigrants perceive group boundaries as more permeable and be less inclined to improve their group's position.
\end{abstract}

Key words: dual identity, superordinate identification, collective action, ethnic migrants 


\section{The ironic effect of national identification on support for collective action}

\section{Introduction}

Previous research has suggested that not only subgroup, but also superordinate identification is needed for the politicization of immigrants in the form of collective action (e.g., Klandermans, 2002; Simon \& Grabow, 2010). Namely, it has been argued that only by virtue of their membership in broader community are subgroup members entitled to societal support for their claims (Simon \& Klandermans, 2001, p. 326; see also Wenzel, 2000). However, some studies have also suggested that this is not always the case. Ironically, dual identification can lead to accepting the ingroup's disadvantaged position — especially under certain social or political conditions (Klandermans, van der Toorn, \& van Stekelenburg, 2008). In one recent example, Wiley and colleagues (2014) found in their study among Latin immigrants in the United States that dual Latino and American identification was not associated with collective action when exclusionist policies were made salient. Another line of empirical research has suggested that while strong subordinate identification seems to promote collective action (Klandermans, 2002; Van Zomeren, Postmes, \& Spears, 2008), common superordinate identification is responsible for making disadvantaged group members accept prevailing inequalities instead of engaging in collective action (Jaśko \& Kossowska, 2013; Ufkes, 2014). Dixon, Durrheim, Kerr and Thomae (2013) have pointed out that the process of recategorization is central for superordinate identification: along with recategorization, subgroups are seen within the same superordinate category and the perceived permeability of group boundaries is increased (for discussion, see Martinovic \& Verkuyten, 2014). In this study, we propose that the perceived permeability of group boundaries is a key factor that explains the attenuating effect of national superordinate identification on support for collective action.

According to social identity theory (Tajfel \& Turner, 1979), characteristics of social structures, such as the permeability of group boundaries, affect people's inclination to protest. 
However, there is still not much research conducted outside of laboratory settings that would assess the significance of these quite abstract structural factors on people's willingness to engage in collective action (for a similar notion, see Van Stekelenburg \& Klandermans, 2013). Thus, in this study we focus on perceived permeability and utilize a longitudinal real-life sample of Ingrian Finns, ethnic migrants from Russia to Finland. We suggest that immigrants' perceptions of group boundaries largely reflect their social identities, which develop and change over the course of the acculturation process. Further, we expect these perceptions of permeability to account for their willingness to engage in and support collective action benefitting the ingroup.

Ingrian Finns are descendants of ethnic Finns who emigrated from Finland to Russia between the 17th and the beginning of the 20th century. After the collapse of the Soviet Union, Russian nationals of Finnish descent and their family members gained the right to migrate to Finland. This accounts for much of Finland's rapidly increasing Russian-speaking population; 23 per cent of all non-native Finnish, Swedish or Sami speakers speak Russian as their mother tongue (Statistics Finland, 2014). The status of Ingrian Finns has been found to be relatively higher than that of other immigrants from Russia to Finland (Liebkind et al., 2004), but due to their relative mononlingualism in Russian, Ingrian Finns are often treated as Russians by the Finnish majority and consequently suffer from prejudice and discrimination like other Russian-speaking groups in the country (see, e.g., Varjonen, Arnold, \& Jasinskaja-Lahti, 2013) ${ }^{1}$.

Although ethnic migrants often face rejection and questioning of their identity, their identification with host nationals is typically high, and being treated as a full member of the society is typically expected (Tartakovsky, 2008; Mähönen \& Jasinskaja-Lahti, 2013). Also, due to their preparations before migration (e.g., taking an obligatory language and cultural course provided by Finnish authorities), it is plausible that these migrants may see boundaries as relatively permeable. Importantly, to have an effect, it is not necessary that the boundaries are seen as totally permeable.

\footnotetext{
${ }^{1}$ Because of this, and because of the transnational ties these diaspora migrants have, we focus in the present study on their Russian (and not Ingrian Finnish ) minority identification.
} 
A classic study by Wright, Taylor and Moghaddam (1990) showed that-even under conditions of only very slight permeability—disadvantaged group members refrain from collective action and take up individual strategies of social mobility. Thus, we propose that Ingrian Finnish migrants' high level of identification with the national majority is reflected in a higher degree of perceived possibilities of being treated as 'one of us' by majority group members, which in turn is associated with lower levels of support for collective action on behalf of immigrants from Russia.

In this three-wave study, we test the indirect association between immigrants' superordinate identification and their support for collective action. Based on the previous research presented above, we expect that Finnish national identification at T1 will be indirectly associated with lower levels of collective action at T3, via the perceived permeability of group boundaries at T2 (H1), when controlling for the level of perceived permeability at T1. Optimally, testing of causality would have required a control for T2 collective action, but in this study, support for collective action was not measured before T3. Acknowledging that previous research has found strong subordinate identification to promote collective action (Klandermans, 2002), we also test for the direct positive association between Russian minority identification at $\mathrm{T} 1$ and support for collective action at T3 $(\mathrm{H} 2)$. With regard to our DV, when predicting collective action with identification, effect sizes have been shown to be stronger for attitudinal measures of collective action as compared to measures of action intentions and behaviour (Van Zomeren et al., 2008). In addition, we argue that, especially when studying recent immigrants who are not politically organized, also attitudes towards the collective action of the minority community should be assessed - not solely personal willingness to engage in collective action. Thus, we simultaneously predict two types of attitudes towards collective action: personal willingness to engage in collective action and perceived need of the community to engage in it. However, we refrain from formulating separate hypotheses for these two dependent variables. The hypothesized model is presented in Figure 1. 
Insert Figure 1 about here

\section{Method}

\section{Participants}

We use data from the three post-migration waves of the four-wave INPRES/LADA ${ }^{2}$ research program, which examines the acculturation process of Ingrian Finns starting from the pre-migration stage (for information about the baseline data $(N=224)$ collected at the pre-migration stage, see Jasinskaja-Lahti et al., 2012). The T1 data of the present study were collected in Finland among recent migrants (time of residence $M=9.3$ months, $S D$ 4.0, range 3 to 15 months). These data were collected between October 2009 and April 2010 (T1, $N=153 ; 72 \%$ female; age $M=45.5$ years, $S D$ = 14), the T2 data between December 2011 and April $2012(N=136 ; 71 \%$ female; age $M=46.3$ years, $S D=14)$, and the T3 data between September 2012 and January $2013(N=85 ; 73 \%$ female; age $M=49.3$ years, $S D=14$ ). Participants were approached using contact information gained from the Finnish National Population Register. In addition to sending reminder letters, participants were encouraged to take part in the study by offering small gifts worth up to 10 euros. Participation in all stages of the project was voluntary, and consent for collecting follow-up data was obtained from each participant.

Of those baseline participants $(N=224)$ who had migrated to Finland by the time of the first follow-up, almost all (95\%) continued participating in the study. After that point, the number of participants decreased, with 86 per cent of T1 participants taking part in the T2 measurement wave. Of the 112 potential participants who had at $\mathrm{T} 2$ given their permission at $\mathrm{T} 2$ to contact them for a final follow-up, 85 took part at T3 (76\% of those giving their consent; $63 \%$ of all

\footnotetext{
${ }^{2}$ INPRES (i.e., Intervening at the pre-migration stage: Providing tools for promoting integration and adaptation throughout the migration process) project 2008-2011; LADA (i.e., Longitudinal analysis of diaspora migration from Russia to Finland) project 2012-2015.
} 
T2 participants). At that time, participants had lived in Finland for approximately three or four years ( $M=34$ months, $S D=3.9$, range 27 to 40 months). Because the most notable drop in the rate of participation occurred in the last measurement wave, we focused our attrition analyses on this stage. In the earlier stages, no statistically significant selection bias was detected based on demographic variables (see Jasinskaja-Lahti et al., 2012). Support for collective action was measured only at T3, but we compared relevant demographic factors (i.e., gender, age, marital status, socioeconomic status, employment status, Finnish language proficiency, health status), as well as T2 Finnish national and Russian minority identification, and the perceived permeability of group boundaries between participants who did or did not participate in the last T3 data collection of the present study. No statistically significant differences were found.

\section{Measures}

\section{Identification}

A six-item scale adapted from Mlickli and Ellemers (1996) and Phinney and Devich-Navarro (1997) was used at T1 and T2 to measure 1) Finnish national and 2) Russian minority identification (e.g., "I see myself as a member of Finnish society/a Russian", "I am proud of being a member of Finnish society/a Russian”). Response options ranged from $1=$ strongly disagree to $5=$ strongly agree, with higher scores denoting higher level of identification. The reliabilities of Finnish national and Russian minority identification scales were $\alpha=.89$ and $\alpha=.94$, respectively.

\section{Permeability}

The perceived permeability of group boundaries was measured at T1 and T2 with three items adapted from Mummendey, Klink, Mielke, Wenzel, and Blanz (1999). The items were: "No matter what effort s/he makes, a Russian immigrant will never become one of the Finns", "For a Russian immigrant it is nearly impossible to be regarded in Finland as one of the Finns", and "In principle, it 
is not difficult for a Russian immigrant to be considered in Finland as one of the Finns". The items were marked on a five-point scale ranging from 1 (totally disagree) to 5 (totally agree), and reversed so that higher scores denoted higher levels of perceived permeability. The reliability of this scale was $\alpha=.80$ at $\mathrm{T} 1$ and $\alpha=.71$ at $\mathrm{T} 2$.

\section{Support for collective action}

Attitudes towards collective action were measured at T3 with seven items developed for the present study. Personal willingness to engage in collective action was measured with the following items: "I am ready to: (1) defend the rights of Russian-speaking immigrants in public debates; (2) verbally intervene in public, if I notice that Russian-speaking immigrants are discriminated against; (3) take part in cultural events organized by Russian-speaking immigrants in Finland”. With regards to support for the collective action of the Russian-speaking community, participants were asked: "In your opinion, should the Russian-speaking community in Finland contribute to the improvement of the situation of Russian-speaking immigrants in the country?" The participants expressed whether the "Russian-speaking community in Finland should: (1) have its own candidate in political elections, (2) defend the rights of Russian-speaking immigrants in public debates, (3) be ready to verbally intervene in public if Russian-speaking immigrants are discriminated against, and (4) organize cultural events for Russian-speaking immigrants in Finland. Both scales were marked on a five-point scale ranging from 1 (totally disagree) to 5 (totally agree), with higher scores denoting higher levels of support for collective action. The reliabilities of the scales measuring support for collective action were $\alpha=.87$ (personal) and $\alpha=.85$ (community).

\section{Data analysis}

The hypotheses were tested with path analysis; due to the small sample size at T3, observed instead of latent indicators for all variables were used. The hypothesized model was tested with Mplus 
software, version 5.21 (full information Maximum Likelihood estimation). Indirect associations were tested with the bootstrapping method with 5000 resamples.

\section{Results}

Descriptive statistics are presented in Table 1. On average, support for collective action was quite high on both measures. The dependent variables correlated in expected directions with the predictors, but there was no statistically significant correlation between Russian identification and the rest of the variables. It should also be noted that there was quite a strong correlation between the two collective action measures, even though in exploratory Principal Component Analysis (with Direct Oblimin rotation) they formed two clearly distinct components (see Table 2).

Insert Table 1 about here

When testing the hypothesized model of the study (see Figure 2), the model fit was acceptable $\left(\chi^{2}(3, N=153)=6.57, p=.087, \mathrm{CFI}=.958, \mathrm{RMSEA}=.088(\mathrm{CI} 90 \%: .000\right.$ to .181$)$. There were no direct associations between Russian identification and the two collective action measures, or between national identification and the two collective action measures. However, as regards our key interest, i.e., the hypothesized indirect association between national identification and support for collective action (H1), we found a marginally significant effect on support for the Russian-speaking community's collective action (indirect effect $=-.05$ (S.E. $=03$ ), $p=.059$, bias corrected CI 95\% = -.11 to .00). However, there was no evidence of an indirect effect of national identification on personal willingness to engage in collective action (indirect effect $=-.01(\mathrm{~S} . \mathrm{E} .=$ 03), $p=.739$, bias corrected CI 95\% $=-.07$ to .05$)$.

To summarize, H1 was supported when predicting support for the Russian-speaking community's collective action. Even though the indirect effect was only marginally significant, the 
simple effect of $\mathrm{X}$ (national identification) on $\mathrm{M}$ (perceived permeability) was significant, as was the partial effect of the M on Y when controlling for X (see Judd, Yzerbyt, \& Muller, 2014 on procedures for assessing mediation). Importantly, as the level of perceived permeability of group boundaries at T1 was controlled for, our longitudinal design provided a rather conservative test of the effect of national identification at T1on perceived permeability at T2. Hence, the test of the indirect effect that includes this path was also conservative.

Insert Figure 2 about here

\section{Additional analyses}

As noted above, subordinate Russian identification and support for community collective action were not associated. It could be argued that such an association would depend on the level of perceived discrimination (Wiley et al., 2014) - the unjust treatment of one's ingroup (Tajfel \& Turner, 1979). Thus, we conducted post-hoc tests to exclude possible interactions between perceived discrimination and Russian minority identification at T1. No significant interactions were found when predicting support for collective action at T3 $(\beta=-.70, p=.137$ for community's collective action, and $\beta=-.50, p=.307$ for personal collective action). Thus, it seems that it is national superordinate identification that mostly accounts for recent ethnic migrants' attitudes towards collective action.

As collective action has been suggested to require not only perceptions of impermeable group boundaries but also perceptions of illegitimate treatment (Tajfel \& Turner, 1979), it could also be asked whether the association between perceived permeability and support of collective action depends on the level of perceived discrimination. However, no significant interactions were found between perceived permeability and discrimination at $\mathrm{T} 1$ when predicting 
support for collective action at T3 ( $\beta=-.48, p=.225$ for support for community's collective action, and $\beta=.12, p=.775$ for personal willingness to engage in collective action).

Finally, we tested the hypothesized model separately for the two collective action measures to make sure that possible indirect effects on support for personal collective action are not camouflaged because of the covariance between the two dependent variables. Again, when predicting support for community's collective action $\left(\chi^{2}(2, N=153)=6.47, p=.039, \mathrm{CFI}=.925\right.$, RMSEA $=.121(\mathrm{CI} 90 \%: .023$ to .230$))$, the indirect effect of national identification was marginally significant $(-.047($ S.E. $=.03), p=.076$, bias corrected CI 95\% $=-.11$ to .00$)$. However, it should be noted that the model fit was suboptimal. When predicting personal willingness to engage in collective action $\left(\chi^{2}(2, N=153)=2.88, p=.237, \mathrm{CFI}=.982, \mathrm{RMSEA}=.054(\mathrm{CI} 90 \%: .000\right.$ to $.178)$ ), there was no indirect effect of national identification (-.01 (S.E.=.03), $p=.725$, bias corrected CI $95 \%=-.07$ to .05$)$. Thus, the interpretation of the results does not depend on whether the two measures of support for collective action are in the same or separate models.

\section{Discussion}

To our knowledge, this study was the first to show the mediating role of perceived permeability of group boundaries in the relationship between national superordinate identification and support for collective action. Namely, immigrants' national identification was associated with lower levels of support for collective action via increased permeability. However, this association was found when predicting attitudes towards the collective action of the Russian-speaking minority in Finland, but not when assessing personal willingness to engage in collective action. One possible reason for this can be found from studies on perceived discrimination; the unfair treatment of one's ingroup is typically reported to a greater degree than personal experiences of discrimination (see, e.g., Taylor, Wright, Moghaddam, \& Lalonde, 1990). Thus, it is possible that collective action is also seen as 
more important when it is a matter of the ingroup rather than oneself (for discussion, see also Haslam, 2004, and the study by Wright et al., 1990, on personal vs. group deprivation).

Concerning limitations and points for future research to address, first, the sample size did not allow for full structural equation modeling nor for the controlling for all variables of interest at each time point. Second, support for collective action was measured only at T3 and, thus, could not be controlled for at earlier time points. Because of this, the suggested causal direction from permeability to collective action is not firmly established by these data and should be interpreted with caution.

More longitudinal and experimental research is needed to confirm the suggested causal paths. Third, as the group studied was culturally and ethnically close to the majority, permeability might play a greater role in collective action tendencies as compared to other immigrant groups. It should also be noted that in the present sample, Russian minority identification was negatively associated with national superordinate identification. This is quite common in European immigration contexts, where many immigrants and ethnic minority group members find it difficult to combine subgroup identities with commitments to the nation-state (see e.g. Verkuyten \& Yildiz, 2007). To confirm the generalizability of the present findings, more research conducted among various immigrant and other minority groups in different intergroup contexts is needed.

To summarize, this study showed the value of approaching support for collective action not only in terms of the individual's responsibility but also the community's. It also contributed to the discussion on the ironic effects of superordinate identification (Jaśko \& Kossowska, 2013) and intergroup contact (e.g., Saguy, Tausch, Dovidio, \& Pratto, 2009). While identification with broader society can be seen as a positive indicator of immigrant integration, being close to the majority also allows immigrants perceive group boundaries as more permeable, making them less inclined to improve the position of the ingroup. 


\section{References}

Dixon, J., Durrheim, K., Kerr, P., \& Thomae, M. (2013). 'What's so funny 'bout peace, love and understanding?' Further reflections on the limits of prejudice reduction as a model of social change. Journal of Social and Political Psychology, 1(1), 239-252. DOI: 10.5964/jspp.v1i1.234.

Haslam, S. A. 2004. Psychology in organizations: The social identity approach, 2nd ed. London: Sage.

Jasinskaja-Lahti, I., Mähönen, T. A., \& Ketokivi, M. (2012). The dynamics of ethnic discrimination, identities and outgroup attitudes: A pre-post longitudinal study of ethnic migrants. European Journal of Social Psychology, 42(7), 904-914. DOI: 10.1002/ejsp.1916.

Jaśko, K., \& Kossowska, M. (2013). The impact of superordinate identification on the justification of intergroup inequalities. European Journal of Social Psychology, 43(4), 255262. DOI: 10.1002/ejsp.1946.

Judd, C. M., Yzerbyt, V. Y., \& Muller, D. (2014). Mediation and moderation. In H. T. Reis \& C. M. Judd (eds.), Handbook of research methods in social and personality psychology, 2nd edition (pp. 653-676). Cambridge: Cambridge University Press.

Klandermans, B. (2002). How group identification helps to overcome the dilemma of collective action. American Behavioral Scientist, 45(5), 887-900. DOI:

$10.1177 / 0002764202045005009$.

Klandermans, B., Van der Toorn, J., \& Van Stekelenburg, J. (2008). Embeddedness and identity: How immigrants turn grievances into action. American Sociological Review, 73(6), 9921012. DOI: 10.1177/000312240807300606.

Liebkind, K., Mannila, S., Jasinskaja-Lahti, I., Jaakkola, M., Kyntäjä, E., \& Reuter, A. (2004). Venäläinen, virolainen, suomalainen. Kolmen maahanmuuttajaryhmän kotoutuminen 
Suomeen. [Russian, Estonian, Finnish. The adaptation of three immigrant groups to Finland.] Helsinki: Gaudeamus.

Martinovic, B., \& Verkuyten, M. (2014). The political downside of dual identity: Group identifications and religious political mobilization of Muslim minorities. British Journal of Social Psychology, 53, 711-730. DOI: 10.1111/bjso.12065.

Mlicki, P., \& Ellemers, N. (1996). Being different or being better? National stereotypes and identifications of Polish and Dutch students. European Journal of Social Psychology, 26, 97-114. DOI:10.1002/(SICI)1099-0992(199601)26:1.

Mummendey, A., Klink, A., Mielke, R., Wenzel, M., \& Blanz, M. (1999). Socio-structural characteristics of intergroup relations and identity management strategies: Results from a field study in East Germany. European Journal of Social Psychology, 29, 259-285.

Mähönen, T. A., \& Jasinskaja-Lahti, I. (2013). Acculturation expectations and experiences as predictors of ethnic migrants' psychological well-being. Journal of Cross-Cultural Psychology, 44(5), 786-806. DOI: 10.1177/0022022112466699.

Phinney, J., \& Devich-Navarro, M. (1997). Variations in Bicultural Identification Among African American and Mexican American Adolescents. Journal of Research on Adolescence, 7, 3-32. DOI:10.1207/s15327795jra0701_2.

Saguy, T., Tausch, N., Dovidio, J. F., \& Pratto, F. (2009). The irony of harmony: intergroup contact can produce false expectations for equality. Psychological Science, 20(1), 114-121. DOI: $10.1111 /$ j.1467-9280.2008.02261.x.

Simon, B., \& Grabow, O. (2010). The politicization of migrants: Further evidence that politicized collective identity is a dual identity. Political Psychology, 31(5), 717-738. DOI: 10.1111/j.1467-9221.2010.00782.x.

Simon, B., \& Klandermans, B. (2001). Politicized collective identity: A social psychological analysis. American Psychologist, 56, 319-331. DOI: 1O.1037//OOO3-066X.56.4.319. 
Statistics Finland (2014). Population structure of Finland in the end of year 2013. Retrieved 12.8.2014 from http://tilastokeskus.fi/til/vaerak/2013/vaerak_2013_2014-0321_tie_001_fi.html.

Tajfel, H., \& Turner, J. C. (1979). An integrative theory of intergroup conflict. The Social Psychology of Intergroup Relations, 33(47), 74.

Tartakovsky, E. (2008). Psychological well-being and ethnic identities of Jewish adolescents planning emigration from Russia and Ukraine to Israel: Changes during the postperestroika period. International Journal of Intercultural Relations, 32, 553-564. DOI:10.1016/j.ijintrel.2008.07.001.

Taylor, D. M., Wright, S. C., Moghaddam, F. M., \& Lalonde, R. N. (1990). The personal/group discrimination discrepancy perceiving my group, but not myself, to be a target for discrimination. Personality and Social Psychology Bulletin, 16(2), 254-262. DOI: $10.1177 / 0146167290162006$.

Ufkes, E. (2014, July). A dual pathway approach to understanding how common ingroup identity undermines collective action. Paper presented at the 17th EASP General Meeting, Amsterdam, the Netherlands.

Van Stekelenburg, J., \& Klandermans, B. (2013). The social psychology of protest. Current Sociology, 61, 886-905. DOI: 10.1177/0011392113479314.

Van Zomeren, M., Postmes, T., \& Spears, R. (2008). Toward an integrative social identity model of collective action: a quantitative research synthesis of three socio-psychological perspectives. Psychological Bulletin, 134(4), 504. DOI: 10.1037/0033-2909.134.4.504.

Varjonen, S., Arnold, L., \& Jasinskaja-Lahti, I. (2013). 'We're Finns here, and Russians there': A longitudinal study on ethnic identity construction in the context of ethnic migration. Discourse \& Society, 24(1), 110-134. DOI: 10.1177/0957926512463632. 
Verkuyten, M., \& Yildiz, A. A. (2007). National (dis) identification and ethnic and religious identity: A study among Turkish-Dutch Muslims. Personality and Social Psychology Bulletin, 33(10), 1448-1462. DOI: 10.1177/0146167207304276.

Wenzel, M. (2000). Justice and identity: The significance of inclusion for perceptions of entitlement and the justice motive. Personality and Social Psychology Bulletin, 26(2), 157 176. DOI: $10.1177 / 0146167200264004$.

Wiley, S., Figueroa, J., \& Lauricella, T. (2014). When does dual identity predict protest? The moderating roles of anti-immigrant policies and opinion-based group identity. European Journal of Social Psychology, 44(3), 209-215. DOI: 10.1002/ejsp.2004.

Wright, S. C., Taylor, D. M., \& Moghaddam, F. M. (1990). Responding to membership in a disadvantaged group: from acceptance to collective protest. Journal of Personality and Social Psychology, 58(6), 994. DOI: 10.1037/0022-3514.58.6.994. 
Table 1. Descriptive statistics of the variables used

\begin{tabular}{|c|c|c|c|c|c|c|c|}
\hline Variable & 1. & 2. & 3. & 4. & 5. & $M$ & $S D$ \\
\hline 1. Finnish identification $T_{1}$ & & & & & & 3.28 & .82 \\
\hline 2. Russian identification $\mathrm{T}_{1}$ & $-.22 *$ & & & & & 3.11 & 1.16 \\
\hline 3. Permeability $\mathrm{T}_{1}$ & $.36 * *$ & .07 & & & & 2.25 & .93 \\
\hline 4. Permeability $\mathrm{T}_{2}$ & $.39 * *$ & -.03 & $.54 * *$ & & & 2.10 & .87 \\
\hline 5. CA personal $\mathrm{T}_{3}$ & -.21 & .05 & $-.26 *$ & -.11 & & 3.75 & .87 \\
\hline 6. CA community $\mathrm{T}_{3}$ & $-.22 *$ & .22 & $-.34 * *$ & $-.26^{*}$ & $.54 * *$ & 4.02 & .74 \\
\hline
\end{tabular}

Note: $* p<.05, * * p<.01 . N=153$ at $\mathrm{T} 1,136$ at $\mathrm{T} 2$ and 85 at $\mathrm{T} 3$. When computing correlations, pairwise deletion was used.

Table 2. Principal Component Analysis on items measuring support for collective action (rotated component matrix)

\begin{tabular}{llll}
\hline Item & Component 1 & Component 2 & Communalities \\
\hline $\begin{array}{l}\text { Community: having a } \\
\text { candidate in elections }\end{array}$ & $\mathbf{. 9 3}$ & .21 & .73 \\
$\begin{array}{l}\text { Community: defending } \\
\text { the rights }\end{array}$ & $\mathbf{. 8 4}$ & -.12 & .81 \\
$\begin{array}{l}\text { Community: organizing } \\
\text { cultural events }\end{array}$ & $\mathbf{. 7 3}$ & -.17 & .65 \\
$\begin{array}{l}\text { Community: intervening } \\
\text { publically }\end{array}$ & $\mathbf{. 7 0}$ & -.20 & .67 \\
$\begin{array}{l}\text { Personal: intervening } \\
\text { publically }\end{array}$ & -.07 & $\mathbf{- 9 4}$ & .86 \\
$\begin{array}{l}\text { Personal: defending the } \\
\text { rights }\end{array}$ & .03 & $\mathbf{- . 9 2}$ & .83 \\
$\begin{array}{l}\text { Personal: taking part in } \\
\text { cultural events }\end{array}$ & .20 & $\mathbf{- . 7 2}$ & .69 \\
\hline
\end{tabular}

Note: Bold figures indicate values $>.30$. The components explained $74.70 \%$ of total variance. 


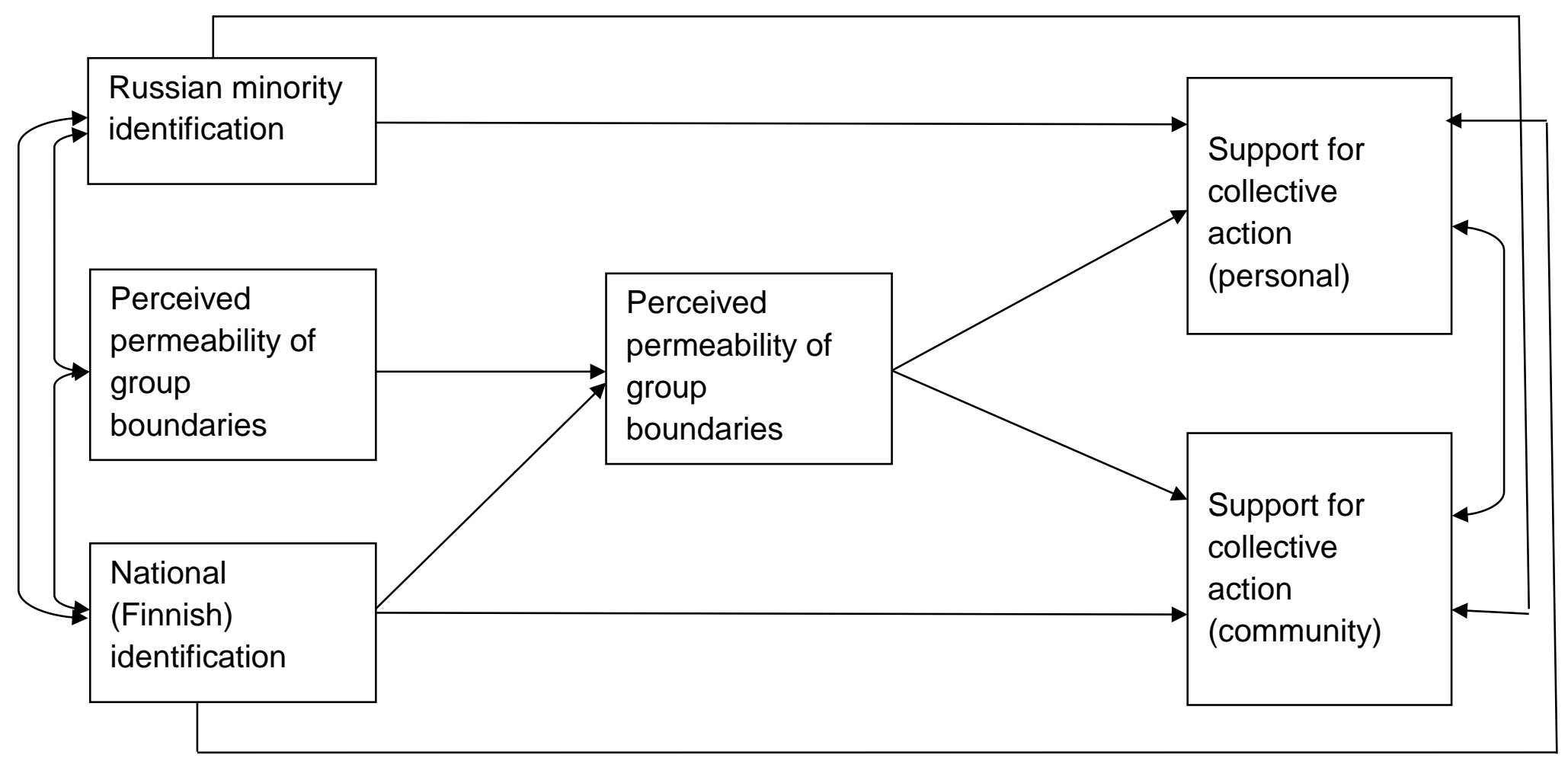

Figure 1. The hypothesized model of the study. 


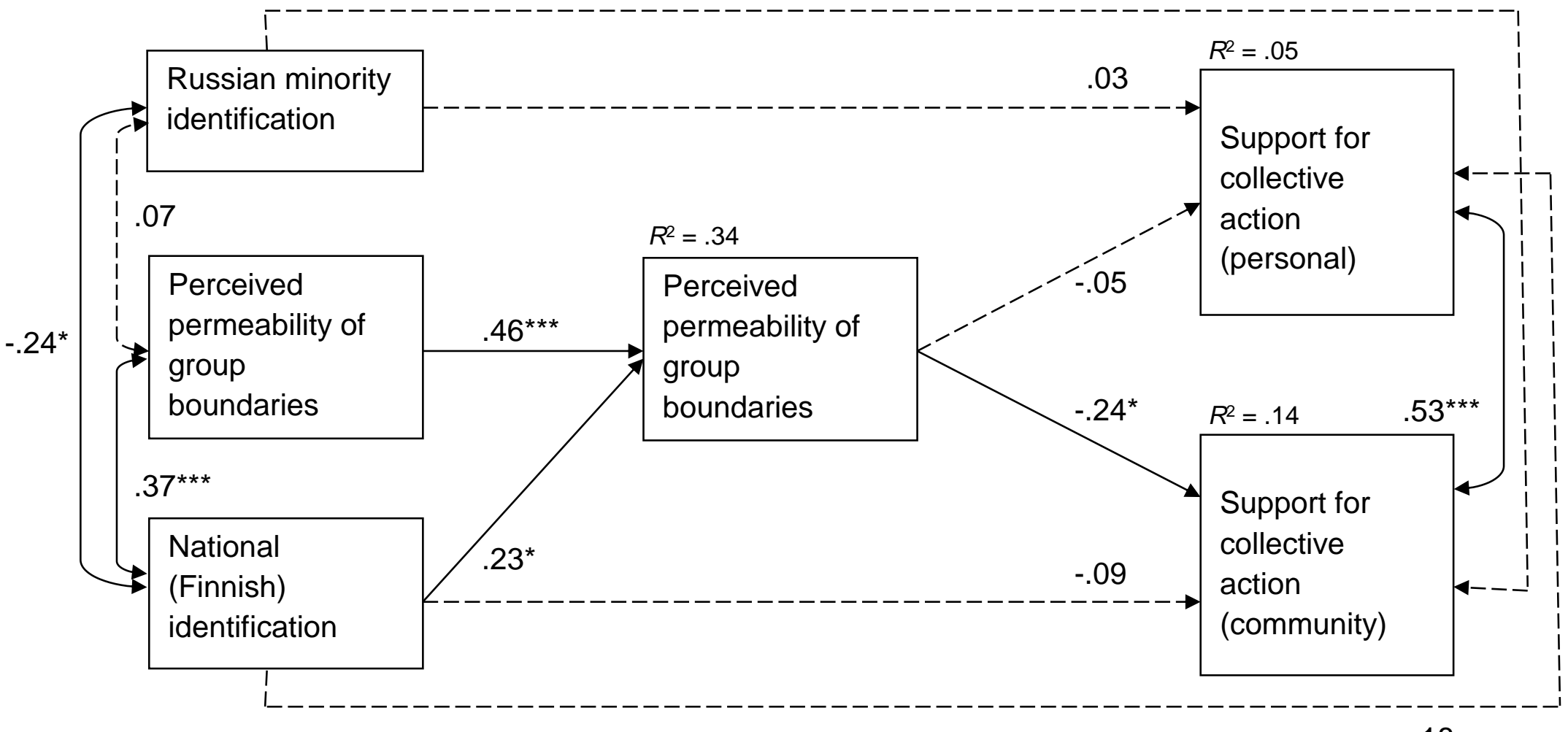

Figure 2. The results of the study (presented with standardized coefficients).

Note: $* p<.05 ; * * * p<.001$ 